\title{
ICAM3 Gene
}

National Cancer Institute

\section{Source}

National Cancer Institute. ICAM3 Gene. NCI Thesaurus. Code C21013.

This gene is involved in the mediation of cellular adhesion, immune responses, and signal transduction. 